\title{
Measurement of apoptosis in long-term cultures of human ovarian tissue
}

\author{
G. Rahimi ${ }^{1}$, E. Isachenko ${ }^{1}$, H. Sauer ${ }^{2}$, M. Wartenberg ${ }^{2}$, \\ V. Isachenko ${ }^{1}$, J. Hescheler ${ }^{2}$, P. Mallmann ${ }^{1}$ and F. Nawroth ${ }^{1 *}$ \\ ${ }^{1}$ Department of Obstetrics and Gynaecology and ${ }^{2}$ Institute of Neurophysiology, University of \\ Cologne, Kerpener Str. 34, 50931 Cologne, Germany
}

At present, the long-term culture of ovarian tissue is problematic. The aim of this study was to measure apoptosis in long-term cultures of human ovarian tissue. Biopsies of human ovaries were cultured for 6 weeks. Samples were taken weekly for histological investigation. The apoptotic cells were marked with anti-caspase 3 . Simultaneous to this experiment, other tissue samples were preincubated for $3 \mathrm{~h}$ with $1 \mu \mathrm{mol}$ staurosporine $\mathrm{I}^{-1}$, an inducer of apoptosis, and apoptosis was compared among samples. Furthermore, the proportion of lethal cells was determined weekly. After 6 weeks, 99\% of the tissue samples showed an intact structure. They expanded in all directions on the floor of the multi-wells to form a monolayer. Apoptotic cells could be marked only sporadically (16.3 \pm 5.9 fluorescence (counts per $3600 \mu \mathrm{m}^{2}$ )) after 6 weeks. After preincubation with staurosporine after the same period of culture, the proportion of apoptotic cells was significantly increased compared with that in untreated control samples (66.8 \pm 14.5 versus $16.3 \pm 5.9 \%$, respectively; $P<0.05)$. Under the same experimental conditions, the proportion of lethal cells was $3.6 \pm 0.9,3.9 \pm 2.1$ and $5.2 \pm 1.5 \%$ for weeks 1, 3 and 6, respectively. After preincubation with 1 $\mu$ mol staurosporine $\mathrm{I}^{-1}$, the proportion of pyknotic cells after 6 weeks of culture was significantly higher $(37.2 \pm 4.4 \%)$ than that in control samples $(3.95 \pm 2.05 \% ; P<0.05)$. No significant increase in apoptosis in cultured human ovarian tissue after 6 weeks was observed compared with control tissues on day 1 . These results indicate that under optimal culture conditions it is possible to cultivate human ovarian tissue long term. The influence of long-term culture on hormone synthesis and follicle maturity will be investigated further.

\section{Introduction}

Malignant diseases and their therapies, which often have an adverse effect on fertility, play an important role in the premature loss of ovarian function. Haematologicaloncological diseases in particular often affect people in their reproductive and childhood years. A reduced rate of recurrence and an increased likelihood of survival, as a result of early diagnosis and aggressive therapies, have assisted in the search for ways to preserve the germinative tissue in prepubescent patients and in women wishing to have children (Apperley and Reddy, 1995).

Cryopreservation of oocytes or ovarian tissue is a potential option for these patients. However, the long-term culture of ovarian tissue, which could be part of a future therapy in combination with cryopreservation, is problematic at present.

Problems arise in conducting appropriate studies, owing to the small size and low growth rate of preantral follicles. After developing suitable culture conditions, McGee et al. (1997a) examined survival, growth and differentiation of

*Correspondence

Email: Frank.Nawroth@medizin.uni-koeln.de preantral follicles. In vivo, preantral follicles appear relatively resistant to atresia. However, apoptosis occurs in serum-free medium (McGee et al., 1997b). In isolated human preantral follicles, FSH leads to a reduction in atresia (Roy and Treacy, 1993).

The aim of the present study was to measure apoptosis in long-term cultures of human ovarian tissue.

\section{Materials and Methods}

\section{Ethics of experimentation}

Human ovarian tissue was obtained with informed consent under a protocol approved by the Ethics Board of the University of Cologne, Germany.

\section{Biopsy and cultivation}

Biopsies of ovarian tissue approximately $2 \mathrm{~mm} \times 2 \mathrm{~mm}$ $\times 2 \mathrm{~mm}$ were taken from three women (aged $34.0 \pm 2.0$ years; mean $\pm \mathrm{SD}$ ) during operative laparoscopies (adnexal operations).

Ovarian tissue was transferred immediately to Leibovitz L-15 medium (Sigma, St Louis, MO) at $4^{\circ} \mathrm{C}$ and transported to the laboratory. The tissue was cut into small pieces 
$(1 \mathrm{~mm} \times 1 \mathrm{~mm} \times 1 \mathrm{~mm})$ with a scalpel. Some tissue pieces were fixed directly in $3.5 \%(\mathrm{w} / \mathrm{v})$ paraformaldehyde for $60 \mathrm{~min}$.

Tissue pieces $(n=6-12)$ from each woman were transferred to 24-well multi-well plates (Falcon). One to three slices were placed in each well. The pieces were cultivated in Dulbecco's modified Eagle's medium (DMEM; Gibco BRL, Life Technologies, Karlsruhe) supplemented with 15\% fetal calf serum (FCS; Boehringer, Mannheim), $2 \mathrm{mmol}$ L-glutamine $\mathrm{I}^{-1}$ (Gibco BRL), $\beta$-mercaptoethanol (final concentration $1.0 \times 10^{-6} \mathrm{~mol} \mathrm{I}^{-1}$ ) (Sigma, Deisenhofen), non-essential amino acids (NAA; Gibco BRL; stock solution diluted 1:100), 100 iu penicillin $\mathrm{ml}^{-1}$ (Gibco BRL), $0.1 \mathrm{mg}$ streptomycin $\mathrm{ml}^{-1}$ (Gibco BRL) and 300 miu human recombinant $\mathrm{FSH} \mathrm{ml}^{-1}$ (recFSH; Gonal $\mathrm{F}^{\circledR}$, Serono, Unterschleissheim) in a humidified incubator containing $5 \% \mathrm{CO}_{2}$ in air at $37^{\circ} \mathrm{C}$. The medium was changed every $48 \mathrm{~h}$.

\section{Histology}

Pieces of each tissue specimen were fixed in $3.5 \%(\mathrm{w} / \mathrm{v})$ paraformaldehyde for histology and immunohistochemistry before and during the 6 weeks of culture. The tissue was embedded in paraffin wax, cut into sections $(6 \mu \mathrm{m}$ thickness) and stained with haematoxylin and eosin for histological investigation. The viable and atretic follicles were compared per high power field ( $\times 400$ magnification) and per patient.

\section{Anti-caspase-3 immunolabelling}

Immunohistochemistry was performed with whole ovarian tissue. Imaging of apoptotic cells was monitored by anti-caspase-3 immunolabelling (Cell Signaling Technology, Beverly, MA). Three pieces of tissue were treated with $1 \mu \mathrm{mol}$ staurosporine $\mathrm{l}^{-1}$ (Sigma) in culture for $3 \mathrm{~h}$. The bacterial alkaloid staurosporine is used widely to induce apoptosis in many types of cell (Kruman et al., 1998).

Ovarian tissue was washed three times in TBS and fixed in $3.5 \%(\mathrm{w} / \mathrm{v})$ paraformaldehyde for $1 \mathrm{~h}$ at $4^{\circ} \mathrm{C}$. After washing three times for $5 \mathrm{~min}$ with TBS containing $0.01 \%$ (v/v) Triton-X100 (TBST), the ovarian tissue was incubated with $1 \mathrm{ml}$ blocking buffer for 45-60 $\mathrm{min}(0.01 \%$ (v/v) TBST containing 5\% FCS).

Incubation with primary antibody anti-caspase 3 (1:100 dilution in TBST containing 5\% (v/v) BSA) was performed for $24 \mathrm{~h}$ at $4^{\circ} \mathrm{C}$. After incubation with the primary antibody, the ovarian tissue was washed three times for 5 min each time with $1 \mathrm{ml}$ TBST. As a secondary antibody, a Cy5conjugated goat anti-rabbit IgG (Dianova, Hamburg) was used at a 1:100 dilution for $1 \mathrm{~h}$. The tissue was washed as described above. Fluorescence was monitored with an inverted confocal laser scanning microscope (LSM 410; Zeiss, Jena) using an oil-immersion $\times 25$ objective N.A. 0.80 (Neofluor; Zeiss). Excitation was performed using the $633 \mathrm{~nm}$ band of an He-Ne laser of the confocal setup. Emission was recorded using a longpass LP $655 \mathrm{~nm}$ filter set.
For quantitative immunohistochemistry, confocal images were recorded from ovarian tissue stained with secondary antibodies only (background fluorescence image) and tissue stained with primary and secondary antibodies. The pinhole settings of the confocal setup were adjusted to yield optical slices of $10 \mu \mathrm{m}$ thickness. After subtraction of the background fluorescence, the fluorescence signal (counts) was evaluated by the image analysis software of the confocal setup in $3600 \mu \mathrm{m}^{2}$ areas of interest and was exported routinely for further analysis to Sigma Plot graphic software.

\section{SYTOX green nucleic acid stain}

Imaging of lethal tissue cells was monitored using the fluorescent dye SYTOX green nucleic acid stain (Molecular Probes, Eugene, OR). Short incubation with SYTOX green stains the nucleic acids of dead cells. Fixed tissue was embedded in paraffin wax and cut into serial sections $(6 \mu \mathrm{m}$ thickness). Paraffin wax was removed and the sections were rehydrated. After washing, they were loaded for 5 min with $1 \mu \mathrm{mol}$ SYTOX green $\mathrm{I}^{-1}$. After loading, the sections were washed three times in PBS. For fluorescence excitation, the $488 \mathrm{~nm}$ line of an argon ion laser of the confocal setup was used. Emission was recorded with a $515 \mathrm{~nm}$ longpass filter. The proportion of pyknotic cells was counted in $160 \mu \mathrm{m}^{2}$ regions of interest in different areas of every sample.

\section{Statistical analyses}

Data are given as mean $\pm \mathrm{SD}$ with $n$ denoting the number of experiments performed with different ovarian tissue cultures. In each experiment, at least three pieces of ovarian tissue from each woman were examined. Student's $t$ test for unpaired data was applied as appropriate. A value of $P<0.05$ was considered statistically significant.

\section{Results}

After 6 weeks of culture, 99\% of the tissue samples showed an intact structure. The samples expanded in all directions on the floor of the multi-wells and formed a monolayer (Fig. 1). In the paraffin wax sections, each piece was surrounded by two to four layers of connective tissue cells that looked like a capsule (Fig. 2).

Viable, non-atretic follicles and secondary follicles were observed in freshly collected tissue and in ovarian tissue cultured for up to 6 weeks (Fig. 3). Mitoses in granulosa cells confirmed that cell division was occurring in the cultures. Follicles were observed in both the central and peripheral areas of the cultured pieces of tissue. Follicle morphology did not differ between cultured ovarian tissue and controls.

\section{Culture of ovarian tissue and apoptosis}

The tissue pieces were stained with anti-caspase-3 as described above to investigate whether long-term culture changes the number of apoptotic cells in ovarian tissue. 

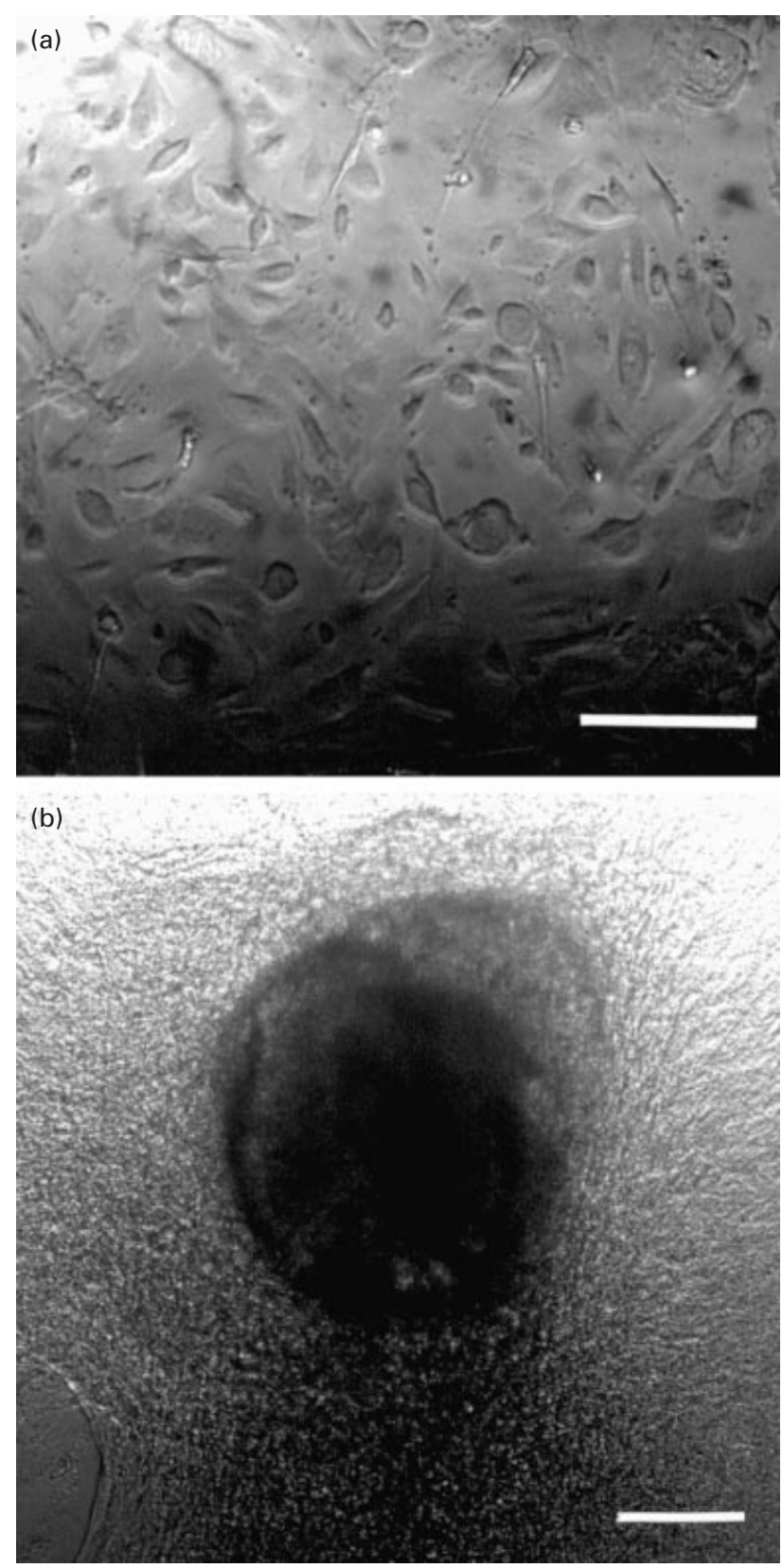

Fig. 1. (a) Formation of a monolayer on the floor of multi-wells after 6 weeks of culture of human ovarian tissue. (b) Expansion of ovarian tissue in all directions on the floor of the multi-wells. Scale bars represent $250 \mu \mathrm{m}$.

After 6 weeks, the apoptotic cells could be marked only sporadically (16.3 \pm 5.9 fluorescence (counts per $\left.3600 \mu \mathrm{m}^{2}\right)$ ). The fluorescence in the control samples was $10.5 \pm 6.3$ on day 1 and $9.1 \pm 7.1$ after 1 week. Two to three pieces of the ovarian tissue from each patient were preincubated for $3 \mathrm{~h}$ with staurosporine $\left(1 \mu \mathrm{mol} \mathrm{\textrm {I } ^ { - 1 }}\right)$, which is an inducer of apoptosis, to determine the number of apoptotic cells produced as a consequence of the apoptotic
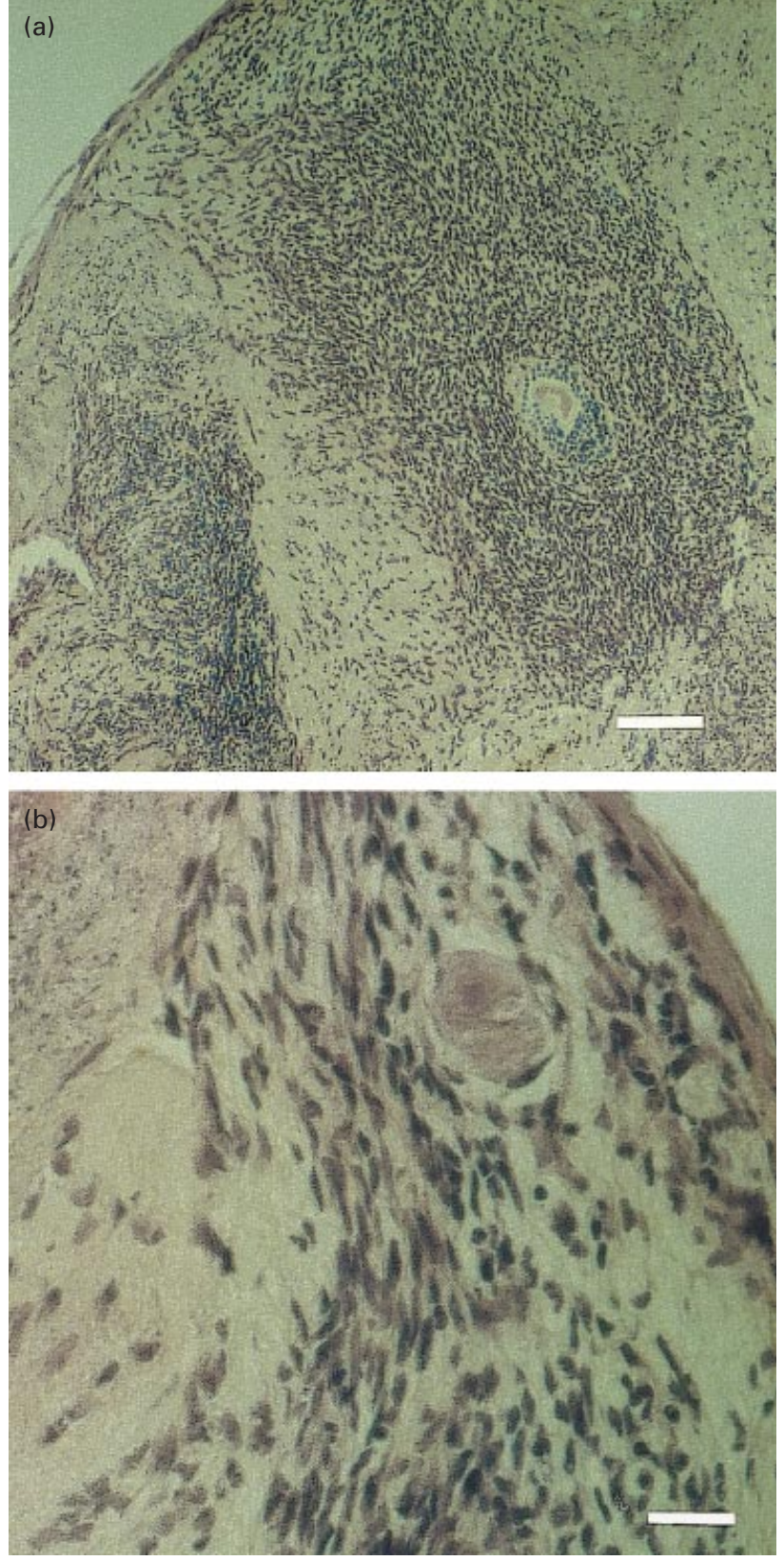

Fig. 2. (a) Low magnification of cultured human ovarian tissue after 6 weeks. In the paraffin wax sections each piece of tissue is surrounded by a capsule of two to four layers of connective tissue cells. (b) High magnification of a small part of the capsule and a follicle in the primordial stage. Scale bars represent (a) $100 \mu \mathrm{m}$ and (b) $25 \mu \mathrm{m}$.

induction. After preincubation of ovarian tissue with staurosporine, the proportion of apoptotic cells of each tissue was significantly higher compared with that in untreated control samples $(66.8 \pm 14.5$ and $16.3 \pm 5.9 \%$, respectively) ( $n=3$ for each experimental condition) (Fig. 4). The fluorescence after preincubation with staurosporine 


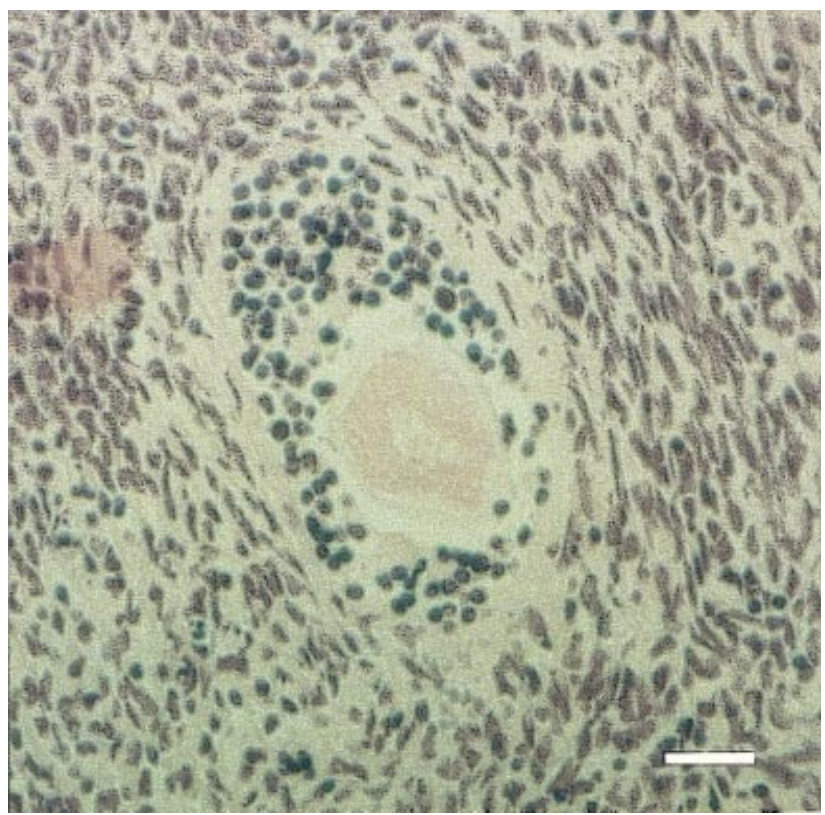

Fig. 3. Human follicle after 6 weeks of culture with a germinal vesicle oocyte surrounded by cumulus cells. Haematoxylin and eosin staining. Scale bar represents $25 \mu \mathrm{m}$.

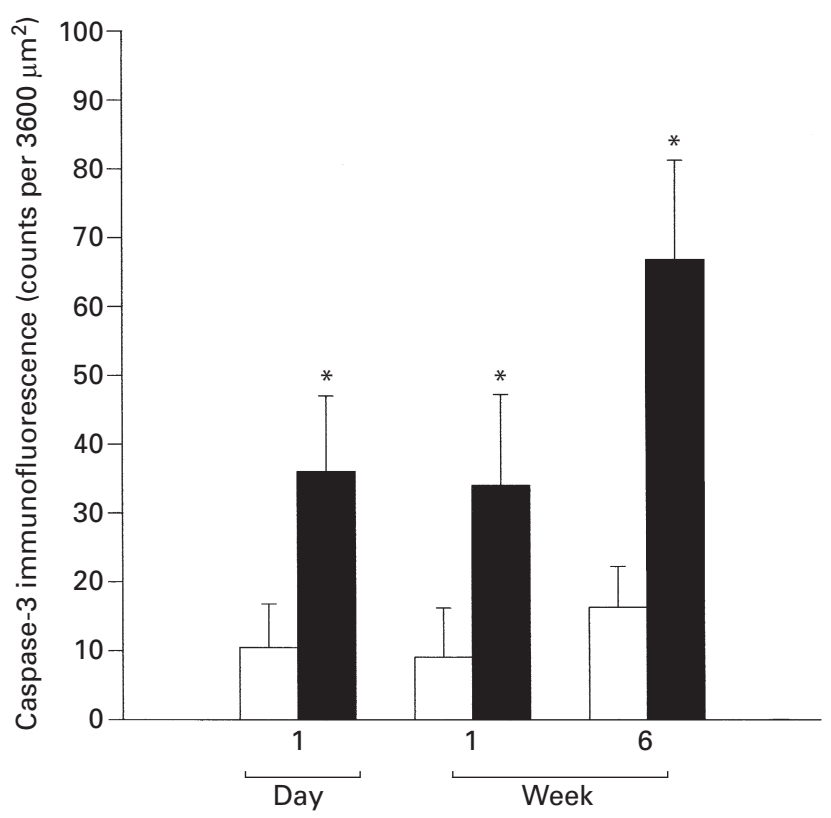

Fig. 4. Caspase- 3 immunofluorescence in human ovarian tissue on day 1 , and after 1 week and 6 weeks of culture, and the effect of preincubation with staurosporine, an inducer of apoptosis of ovarian tissue cells. $\square$ : Control tissue; $\mathbf{\square}$ : tissue preincubated with $1 \mu \mathrm{mol}$ staurosporine $\mathrm{I}^{-1}$. *Significantly different from corresponding control $(P<0.05)$.

on day 1 was $36.0 \pm 11.0$ counts per $3600 \mu \mathrm{m}^{2}$. The increase in caspase-3 immunofluorescence in the treated samples compared with that in the untreated control is shown (Fig. 5).
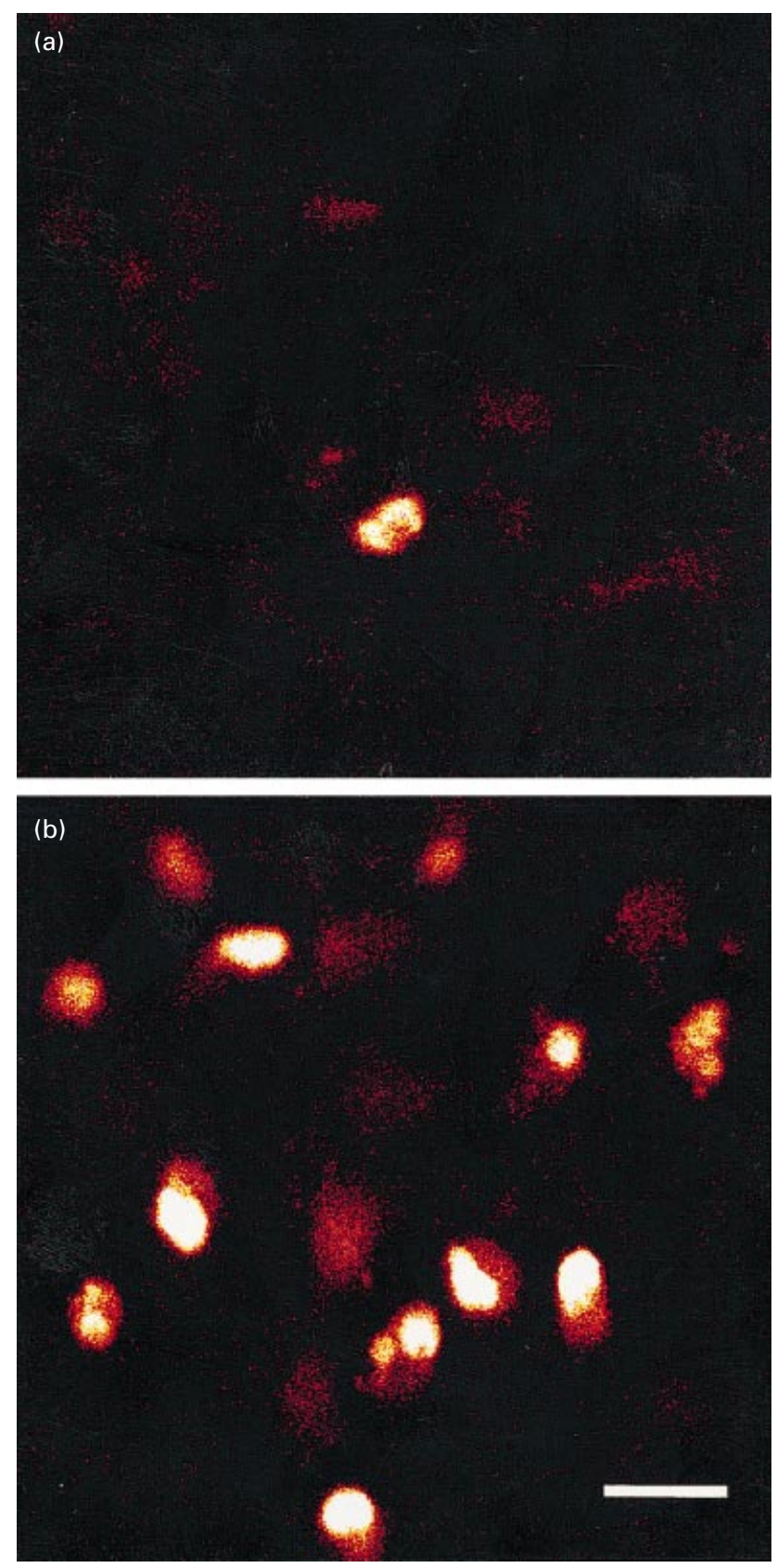

Fig. 5. Immunohistochemical detection of apoptotic cells by anticaspase- 3 staining of cultured human ovarian tissue after 6 weeks of culture. (a) Control tissue and (b) tissue preincubated with $1 \mu \mathrm{mol}$ staurosporine $\mathrm{I}^{-1}$ for $3 \mathrm{~h}$. Scale bar represents $25 \mu \mathrm{m}$.

\section{Culture of ovarian tissue and lethal cells}

The ovarian tissue was loaded with SYTOX green nucleic acid stain $\left(1 \mu \mathrm{mol} \mathrm{I}^{-1}\right)$, which binds with high affinity to the triplex structure of the nucleic acids, to determine whether an increase in lethal cells can be observed during long-term culture. The proportion of lethal cells was not significantly higher than on day 1 (Fig. 6). Under the same experimental 


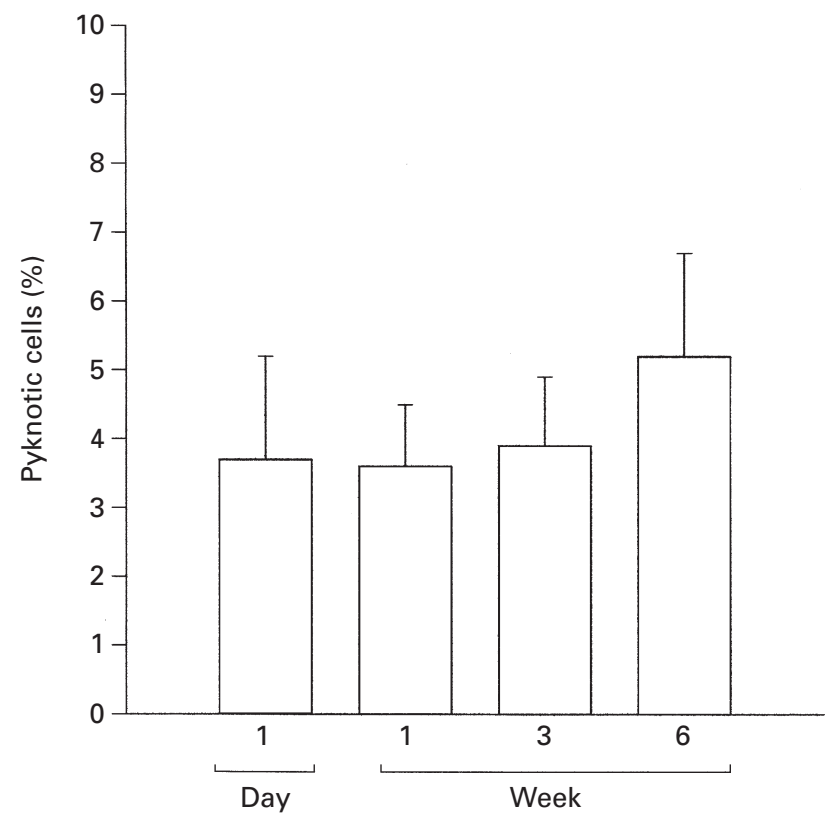

Fig. 6. Percentage of pyknotic cells on day 1 and at different weeks of culture of human ovarian tissue. The tissue pieces were loaded with SYTOX green, which binds to the lethal cells.

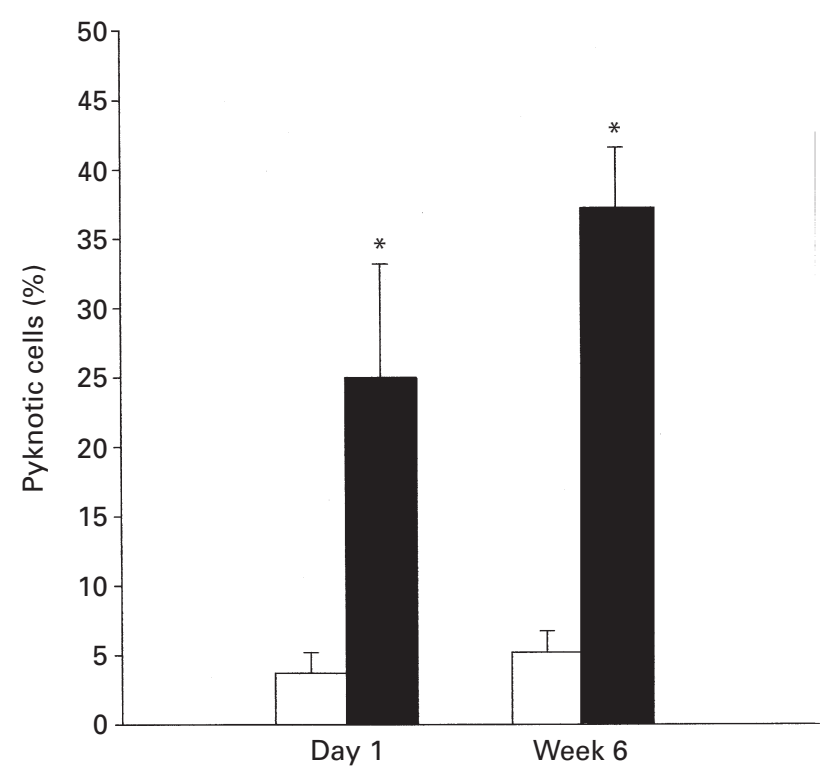

Fig. 7. Percentage of pyknotic cells in cultured human ovarian tissue on day 1 and after 6 weeks of culture. $\square$ : Control tissue; घ: tissue preincubated with $1 \mu \mathrm{mol}$ staurosporine $\mathrm{I}^{-1}$ for $3 \mathrm{~h}$. *Significantly different from corresponding control $(P<0.05)$.

conditions, the proportion of pyknotic cells was $3.6 \pm 0.9$, $3.9 \pm 2.1$ and $5.2 \pm 1.5 \%$ at weeks 1,3 and 6 , respectively ( $n=3$ for each experimental condition). The proportion on day 1 was $3.7 \pm 1.5 \%$. Pyknotic cells are round and show an increased fluorescence.
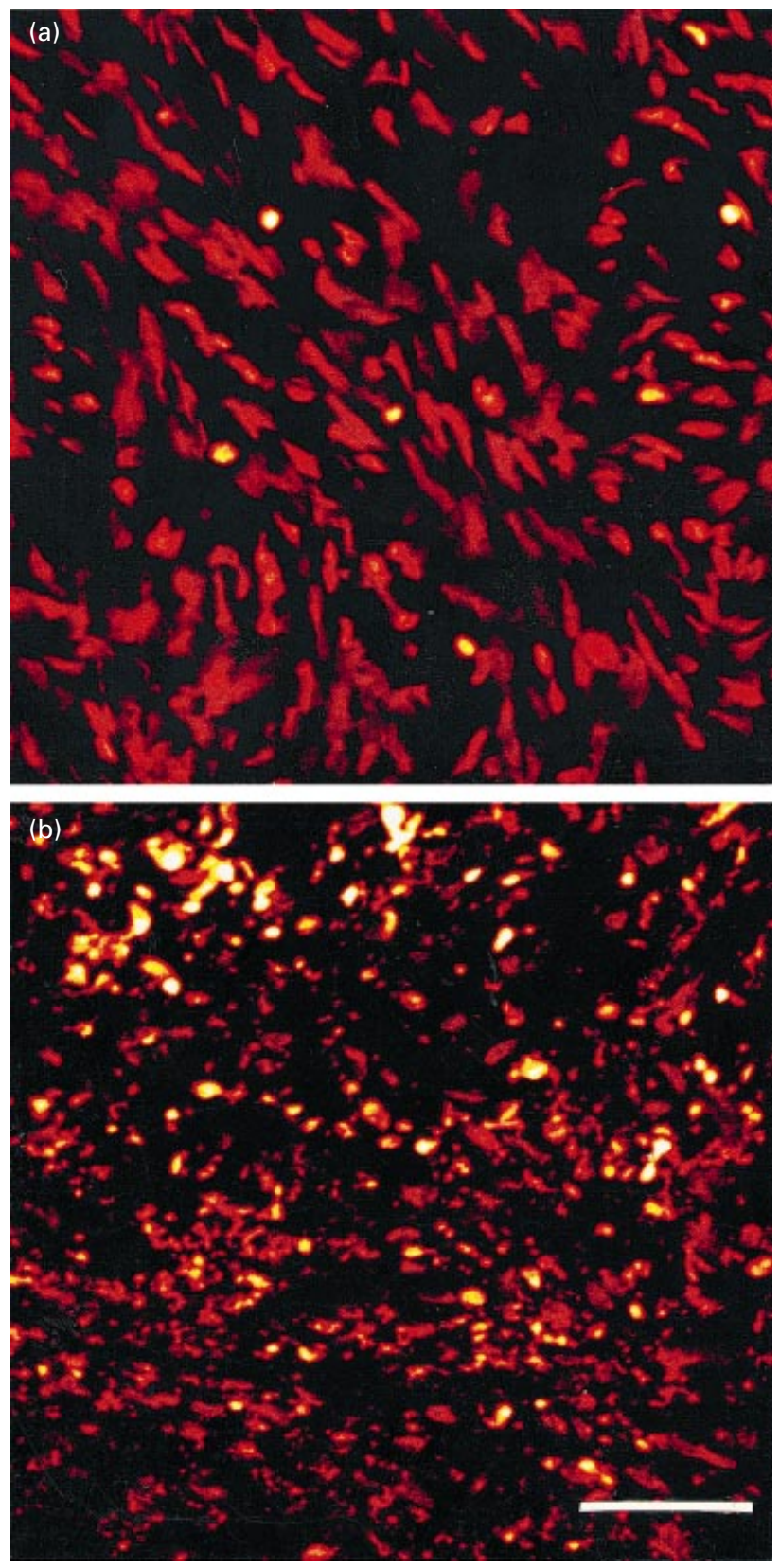

Fig. 8. Pyknotic cells in human ovarian tissue culture. The pyknotic cells are round and show an increased fluorescence after 6 weeks. (a) Control: no staurosporine preincubation. (b) Preincubation of 6 -week-old tissue with $1 \mu \mathrm{mol}$ staurosporine $\mathrm{I}^{-1}$ for $3 \mathrm{~h}$. Scale bar represents $20 \mu \mathrm{m}$.

After preincubation of 6-week-old ovarian tissue with $1 \mu \mathrm{mol}$ staurosporine $\mathrm{I}^{-1}$ for $3 \mathrm{~h}$, the proportion of pyknotic cells was significantly higher $(37.2 \pm 4.4 \%)$ than in the untreated control samples $(3.9 \pm 2.1 \%$ ) (Figs 7 and 8 ). After preincubation with staurosporine on day $1,25.0 \pm 8.2 \%$ of the cells were pyknotic. 


\section{Discussion}

Apoptosis is a morphological process caused by a cellular suicide programme that is associated with physiological or programmed cell death. Wu et al. (2000) found that some oocytes that had matured in vitro underwent apoptosis. The same process occurs in vivo, as oocytes that mature in vivo will degenerate if they are not fertilized. Recent studies have indicated that apoptosis may be the underlying mechanism of ovarian follicle degeneration during atresia (Hughes and Gorospe, 1991; Tilly et al., 1991; Hsueh et al., 1994).

Apoptosis is a process of active and selective cell deletion that requires active gene expression. It is characterized by certain morphological events such as pyknosis of cell nuclei and formation of apoptotic bodies (Kerr et al., 1972).

The morphological changes that occur in granulosa cells of follicles undergoing atresia match all apoptosis-related morphological characteristics (Tsafriri and Braw, 1984).

Several hormones and factors have been reported to play key roles in apoptosis in ovarian tissue. Gonadotrophins and oestrogens prevent apoptosis, and androgens antagonize the effect of oestrogens (Chun et al., 1994; Billig et al., 1995). Drugs and radiation can increase apoptosis in many normal tissues and in some tumours (Thompson, 1995).

Until recently, terminal deoxyribonucleotidyl transferase (TdT)-mediated deoxyuridine triphosphate (dUTP) nick end labelling (TUNEL) was the method of choice to detect apoptosis. However, an increasing number of studies have reported false positive results with this method: TUNEL assay detected DNA repair but not apoptosis in cardiac myocytes (Kanoh et al., 1999); TUNEL reactivity was produced by histological sectioning (Sloop et al., 1999); and false positive TUNEL labelling was detected in mouse kidney and liver (Pulkkanen et al., 2000). Therefore, caspase-3 immunohistochemistry and analysis of pyknotic nuclei were used in the present study.

In the present study, no significant increase in apoptosis was observed in cultured human ovarian tissue after 6 weeks compared with controls on day 1 of culture.

It proved possible to induce apoptosis with staurosporine at different times of culture. This finding indicates that, after long-term culture, death receptors (cell surface receptors) are still able to transmit apoptosis signals initiated by specific 'death ligands'. These receptors have direct access to the caspase system and can activate death caspases within seconds of ligand binding, causing an apoptotic demise of the cell within hours. Death receptors belong to the tumour necrosis factor (TNF) receptor gene superfamily, which is defined by similar, cysteine-rich extracellular domains (Smith et al., 1994).

The results of the present study indicate that 'fresh' human ovarian tissue is less susceptible to apoptosis than cultured ovarian tissue after preincubation with staurosporine.

From these results it is not possible to determine that the two methods used to detect apoptosis yield different rates of apoptosis, as the SYTOX method detected the percentage of pyknotic cells in a defined region of interest $\left(160 \mu \mathrm{m}^{2}\right)$, whereas analysis of the caspase-3 immunofluorescence intensity in a defined region of interest $\left(3600 \mu \mathrm{m}^{2}\right)$ quantified the caspase-3 labelling.

The relationship between commitment to apoptosis and the position of a cell in the cell cycle appears to vary with respect to the type of cell and lethal stimulus.

Staurosporine is a protein kinase inhibitor that blocks G1/S and G2/M cell cycle transitions, resulting in the accumulation of G1 or G2 interphase cells, depending on the applied dosage (Myint and Sit, 1997).

Frozen-thawed human follicles appear viable and capable of further development in culture (Hovatta et al., 1997). This finding indicates that cryopreservation of human ovarian tissue for use in future infertility treatments could be worthwhile. Ovarian biopsy is a relatively simple method to obtain ovarian tissue. Growth of follicles in vitro to stages at which they can be used for IVF would have major benefits for infertile women, clinicians and scientists. It may be especially important to women who are undergoing procedures likely to result in sterilization, such as chemotherapy or radiotherapy (Wood et al., 1997). Ovarian tissue can be removed before treatment begins and cryopreserved until an appropriate time. There is no known risk of transmission of cancerous cells with in vitro maturation, which could occur if the tissue was regrafted (Gosden et al., 1997; Shaw and Trounson, 1997).

The results of the present study indicate that it is possible to culture human ovarian tissue long term under optimal culture conditions. Human primordial or primary follicles can be maintained and are obviously growing in long-term cultures of ovarian tissue from adult women. The presence of secondary follicles can be regarded as evidence of follicular growth.

The influence of long-term culture on hormone synthesis and follicle maturity will be the subject of further study. In addition, which types of cell are more prone to apoptosis during long-term culture will be investigated. Further development of cultures could extend the therapeutic concept with cryopreserved as well as non-cryopreserved tissue, for example, in connection with planned transplantations.

This work was presented in part at the Annual Meeting of the European Society of Human Reproduction and Embryology, Lausanne, Switzerland, 1-4 July, 2001. The project was supported by the Koeln Fortune Program/Faculty of Medicine, University of Cologne and Alexander von Humboldt Foundation. The authors would like to acknowledge M. Priemer for her careful translation of this paper.

\section{References}

Apperley JF and Reddy N (1995) Mechanism and management of treatmentrelated gonadal failure in recipients of high dose chemoradiotherapy Blood Reviews 9 93-116

Billig H, Furuta I, Rivier C, Tapanainen J, Parvinen M and Hsueh AJ (1995) Apoptosis in testis germ cells: developmental changes in gonadotropin 
dependence and localization to selective tubule stages Endocrinology $1365-12$

Chun S, Billig H, Tilly JL, Furuta I, Tsafriri A and Hsueh AJ (1994) Gonadotropin suppression of apoptosis in cultured preovulatory follicles: mediatory role of endogenous insulin-like growth factor I Endocrinology 135 1845-1853

Gosden RG, Rutherford AJ and Norfolk DR (1997) Transmission of malignant cells in ovarian grafts [comment] Human Reproduction 12 403

Hovatta O, Silye R, Abir R, Krausz T and Winston RM (1997) Extracellular matrix improves survival of both stored and fresh human primordial and primary ovarian follicles in long-term culture Human Reproduction 12 1032-1036

Hsueh AJ, Billig H and Tsafriri A (1994) Ovarian follicle atresia: a hormonally controlled apoptotic process Endocrine Reviews 15 $707-724$

Hughes FM and Gorospe WC (1991) Biochemical identification of apoptosis (programmed cell death) in granulosa cells: evidence for a potential mechanism underlying follicular atresia Endocrinology 129 2415-2422

Kanoh M, Takemura G, Misao J et al. (1999) Significance of myocytes with positive DNA in situ nick end-labeling (TUNEL) in hearts with dilated cardiomyopathy: not apoptosis but DNA repair Circulation 99 2757-2764

Kerr JF, Wyllie AH and Currie AR (1972) Apoptosis: a basic biological phenomenon with wide-ranging implication in tissue kinetics British Journal of Cancer 26 239-257

Kruman I, Guo Q and Mattson MP (1998) Calcium and reactive oxygen species mediate staurosporine-induced mitochondrial dysfunction and apoptosis in PC12 cells Journal of Neuroscience Research 51 293-308

McGee EA, Perlas E, LaPolt PS, Tsafriri A and Hsueh AJ (1997a) Folliclestimulating hormone enhances the development of preantral follicles in juvenile rats Biology of Reproduction 57 990-998

McGee E, Spears N, Minami S, Hsu SY, Chun SY, Billig H and Hsueh AJ (1997b) Preantral ovarian follicles in serum-free culture: suppression of apoptosis after activation of the cGMP pathway and stimulation of growth and differentiation by follicle-stimulating hormone Endocrinology 138 2417-2424

Myint S and Sit KH (1997) Staurosporine induces telophase arrest and apoptosis blocking mitosis exit in human chang liver cells Biochemical and Biophysical Research Communications 236 594-598

Pulkkanen KJ, Laukkanen MO, Naarala J and Yla-Herttuala S (2000) Falsepositive apoptosis signal in mouse kidney and liver detected with TUNEL assay Apoptosis 5 329-333

Roy SK and Treacy BJ (1993) Isolation and long-term culture of human preantral follicles Fertility and Sterility 59 783-790

Shaw J and Trounson A (1997) Oncological implications in the replacement of ovarian tissue Human Reproduction 12 403-405

Sloop GD, Roa JC, Delgado AG, Balart JT, Hines MO and Hill JM (1999) Histologic sectioning produces TUNEL reactivity. A potential cause of false-positive staining Archives of Pathology and Laboratory Medicine 122 252-255

Smith CA, Farrah T and Goodwin RG (1994) The TNF receptor superfamily of cellular and viral proteins: activation, costimulation, and death Cell 76 959-962

Thompson CB (1995) Apoptosis in the pathogenesis and treatment of disease Science 267 1456-1462

Tilly JL, Kowalski KI, Johnson AL and Hsueh AJ (1991) Involvement of apoptosis in ovarian follicular atresia and postovulatory regression Endocrinology 129 2799-2801

Tsafriri A and Braw RH (1984) Experimental approaches to atresia in mammals Oxford Reviews of Reproductive Biology 6 226-265

Wood CE, Shaw JM and Trounson AO (1997) Cryopreservation of ovarian tissue. Potential "reproductive insurance" for women at risk of early ovarian failure Medical Journal of Australia 166 366-369

Wu J, Zhang L and Wang X (2000) Maturation and apoptosis of human oocytes in vitro are age-related Fertility and Sterility 74 1137-1141

Received 19 April 2001.

First decision 4 June 2001.

Accepted 26 June 2001 